\title{
RESIDUAL ACTION OF INSECTICIDES TO LARVAE OF Chrysoperla externa (Hagen, 1861) (Neuroptera: Chrysopidae) UNDER GREENHOUSE CONDITIONS
}

\author{
DENILSON BEZERRA COSTA ${ }^{1}$ \\ BRÍGIDA SOUZA ${ }^{2}$ \\ GERALDO ANDRADE CARVALHO ${ }^{2}$ \\ CÉSAR FREIRE CARVALHO ${ }^{2}$
}

\begin{abstract}
This work was designed to evaluate the residual action of the insecticides trichlorfon, triflumuron, endosulfan, fenpropathrin, chlorpirifos, tebufenozide and esfenvalerate, sprayed on cotton plants, to second-instar larvae of Chrysoperla externa (Hagen, 1861), under greenhouse conditions. The experimental design was completely randomized with ten replicates. Three larvae were released on each
\end{abstract}

plant, in the $1^{\text {st }}, 12^{\text {th }}$ and $23^{\text {rd }}$ day after pesticides spray. Tebufenozide and esfenvalerate were little persistent (class one), while trichlorfon, triflumuron and endosulfan were slightly persistent, decreasing the survival of $C$. externa larvae over $30 \%$, up to 14 days after spray. Fenpropathrin and chlorpirifos caused mortality over $30 \%$, up to 25 days after spray, being classified as fairly persistent.

INDEX TERMS: Selectivity, predator, pesticides, cotton.

\section{AÇÃO RESIDUAL DE INSETICIDAS PARA LARVAS DE Chrysoperla externa (Hagen, 1861) (Neuroptera: Chrysopidae) EM CONDIÇÕES DE CASA-DE-VEGETAÇÃ̃O}

\begin{abstract}
RESUMO - Avaliou-se a ação residual dos inseticidas trichlorfon, triflumuron, endosulfan, fenpropathrin, chlorpirifos, tebufenozide e esfenvalerate para larvas de segundo ínstar de Chrysoperla externa (Hagen, 1861) aplicados em plantas de algodoeiro. O delineamento foi inteiramente casualizado, com oito tratamentos e dez repetições. As larvas do predador foram liberadas no $1^{1}$, $12^{\mathrm{o}}$ e $23^{\mathrm{o}}$ dias após as pulverizações, em número de
\end{abstract}

três por planta. O tebufenozide e esfenvalerate foram enquadrados na classe 1 (pouco persistente). O trichlorfon, endosulfan e triflumuron foram classificados como levemente persistentes, reduzindo a porcentagem de sobrevivência das larvas de C. externa em mais de 30\%, até 14 dias após aplicação. Fenpropathrin e chlorpirifos causaram mortalidade superior a $30 \%$ por até 25 dias, sendo classificados como moderadamente persistentes.

TERMOS PARA INDEXAÇÃO: Seletividade, predador, produtos fitossanitários, algodoeiro.

\section{INTRODUCTION}

The use of insecticide to control of cotton pests, in general, does not take into account the effects of these chemicals on beneficial arthropods present on the crop. The preservation and maintenance of the natural enemies in the agroecosystem are essential to the establishment of the biological equilibrium and reduction of the production costs as well as to avoid side effects the chemicals to environment (Gravena \& Cunha, 1991).

The use of highly toxic and broad-spectrum action pesticides is the main cause of biological disturbance in a number of crops, giving rise to phenomena such as pest resurgence, occurrence of secondary pests and selection of populations of resistant insects. The use of selective chemicals is an important strategy within pest management programs, since it reduces the

1. Engenheiro Agrônomo, MSc., Departamento de Entomologia, UNIVERSIDADE FEDERAL DE LAVRAS/UFLA, Caixa Postal 37, 37200-000, Lavras, MG.

2. Professores do Departamento de Entomologia/UFLA. 
population of the phytophagous insects without affecting significantly the natural enemies. To maximize the compatibleness between the chemical and biological controls it is needed to know the selectivity and the conditions of use of an insecticide, in order to reduce its impact on the natural enemies.

The insects of the family Chrysopidae are predators of many species of arthropods, and play an important role in the natural biological control of several crop pests. Among the chrysopids, Chrysoperla externa (Hagen, 1861), a common species in the Neotropical region, is reported to be abundant in cotton agroecosystens (Gravena et al., 1992).

In view of the importance of $C$. externa in the biological control of cotton pests and scarcity of information regarding the impact of insecticides on that species of natural enemy, this work aimed to evaluate the residual action of insecticides used on cotton crops, to second-instar larvae of that predator.

\section{MATERIAL AND METHODS}

The work was conducted in a greenhouse at the Entomology Department of the Universidade Federal de Lavras - UFLA. Newly-hatched larvae of C. externa and from laboratory rearing were individualized in glass tubes $2.5 \mathrm{~cm}$ in diameter by $8.5 \mathrm{~cm}$ in height and fed on eggs of Anagasta kuehniella (Zeller, 1879) (Lepidoptera: Pyralidae) up to the second-instar (about 48 hours after ecdysis), when they were utilized in the trials. The insects were maintained in climatic chambers at $25 \pm 2^{\circ} \mathrm{C}, \mathrm{RH} 70 \pm 10 \%$ and $12 \mathrm{~h}$ photophase.

Seven insecticides utilized for control of cotton leafworm Alabama argillacea (Hübner, 1818) (Lepi- doptera: Noctuidae) were evaluated, by employing the highest dosages recommended by the manufacturers (Table 1). The chemicals were diluted in distilled water, by using a magnetic shaker, to allow complete homogenization. The control treatment was made up of distilled water.

Thirty day-old cotton plants, cultivar IAC 22, planted in polyvinilchloride pots with a capacity of three liters, containing earth $(60 \%)$ and cow manure (40\%), were utilized. The plants were sprayed up to the point of dripping, utilizing a manual sprayer with capacity of $500 \mathrm{ml}$ and, after one, 12 and 23 days, three second-instar larvae of $C$. externa were released on the upper third of each of them. The days for proceeding the releases were chosen randomly, within the interval proposed by the "International Organization for Biological and Integrated Control of Noxious Animals and Plants" - IOBC (Hassan \& Degrande, 1996; Hassan, 1997) (Table 2).

To prevent the escape of larvae, cages made of plastic bottles were use to cover the cotton plants. The upper end of each container was removed, fitting at the opening, a foam disk with a central orifice of diameter enough to allow the perfect fit to the plant's stem. Aiming to warrant the aeration in the inside of the bottles, a side opening $20 \mathrm{~cm}$ long $\mathrm{x} 10$ $\mathrm{cm}$ wide was done, which was sealed with a organza type white fabric, affixed with adhesive tape. Each plant was covered with one of those containers, arranging the foam disk close to the soil surface. For fixation of those frames, in the substrate of each plot, two bamboo stakes $40 \mathrm{~cm}$ long were inserted, these being tied by a elastic strap on its upper end.

TABLE 1 - Commercial names, active ingredients, chemical groups and application rates of the insecticides utilized in the selectivity trial for Chrysoperla externa.

\begin{tabular}{|c|c|c|c|}
\hline Commercial name & Active ingredient & Chemical group & Rate $\left(\right.$ g or $\left.\mathbf{~ m l} / \mathbf{1 0 0 m l ~} \mathrm{H}_{2} \mathrm{O}\right)$ \\
\hline Alsystin $250 \mathrm{PM}$ & triflumuron & Benzoylphenylureas & 0,020 \\
\hline Dipterex $500 \mathrm{CE}$ & trichlorfon & Organophosphate & 1,540 \\
\hline Danimen $300 \mathrm{CE}$ & fenpropathrin & Pyrethroid & 0,125 \\
\hline Sumidan $250 \mathrm{SC}$ & esfenvalerate & Pyrethroid & 0,200 \\
\hline Thiodan $350 \mathrm{CE}$ & endosulfan & Chlorocyclodiene & 1,125 \\
\hline Mimic 240 SC & tebufenozide & Diacylhydrazine & 1,250 \\
\hline Vexter $480 \mathrm{CE}$ & chlorpirifos & Organophosphate & 0,125 \\
\hline
\end{tabular}

Ciênc. agrotec., Lavras. V.27, n.4, p.835-839, jul./ago., 2003 
TABLE 2 - Evaluation intervals, persistence levels and toxicity classes of pesticides according to the "International Organization for Biological and Integrated Control of Noxious Animals and Plants" - IOBC.

\begin{tabular}{ccc}
\hline Evaluation interval & Persistence levels & Classes \\
\hline$<5$ days & little persistent & 1 \\
5-15 days & slightly persistent & 2 \\
16-30 days & moderately persistent & 3 \\
\hline
\end{tabular}

The number of dead larvae in each treatment was examined after 48 hours' exposition to the chemicals, at 3, 14 and 25 days after spraying. The experimental design was that completely randomized, by utilizing ten plants per treatment, the plot being made up of one plant with three larvae of the predator.

Data analysis: The reduction of the number of larvae caused by the action of the insecticides was compared with the control treatment, used as a parameter for classification of the chemicals' toxicity. This classification was determined according to the duration of the toxic activity of the compounds, that is, the interval of time in which its residues caused less than $30 \%$ of mortality, fitting into categories according to the methodology advised by the IOBC (Hassan \& Degrande, 1996; Hassan, 1997) (Table 2).

\section{RESULTS AND DISCUSSION}

Tebufenozide and esfenvalerate presented a rapid loss of residual action after being sprayed on the cotton plants (Table 3), being fit in class 1 (little persistent). The low residual action of esfenvalerate confirms the results found by Carvalho et al. (2002) for that same specie, though another application methodology was utilized. The low mortality $(<30 \%)$ provided by those chemicals on the third day after spraying, is probably due to a greater degradation of the insecticide molecules either on the cotton leaves or in the body of the larvae.

According to $\mathrm{Yu}$ (1988), other mechanisms may be involved in the selectivity of tebufenozide and esfenvalerate to the larvae of $C$. externa, such as: less penetration of these chemicals through the cuticle or alterations in the target of actions of active ingredients. Guedes et al. (1992) reported that the lipophilic character of some insecticides, associated with the thickness and lipidic composition of the insects' cuticle and its trans- location as far as the target of action. Lipophylicity is inversely proportional to the solubility of the insecticide in water; the most lipophylic compounds by their chemical similarity with the cuticle, in general, present greater penetration in the insect's body.

The insecticides trichlorfon, triflumuron and endolsulfan were in the class 2 , being regarded as slightly persistent (Table 3). At 14 days from its application, those insecticides caused less than $30 \%$ of mortality for larvae which had contact with sprayed cotton leaves. As regards to trichlorfon, the results differ from those verified by Hassan et al. (1994) for Chrysoperla sp., who found that insecticide to be in class 1 . That difference may be as related to physiological responses specific to the insects tested, inasmuch as it was not mentioned the species concerned. Lingren \& Ridgway (1967), Hassan et al. (1987) and Toda \& Kashio (1997) also found that larvae of Chrysoperla carnea (Stephens, 1836) were not affected negatively by the trichlorfon.

TABLE 3 - Residual action of insecticides to secondinstar larvae of Chrysoperla externa, when applied on cotton plants in greenhouse. Lavras- MG, 2001.

\begin{tabular}{lcc}
\hline Active ingredient & $\begin{array}{c}\text { Average persistence } \\
\text { (days) }\end{array}$ & Classes $^{\mathbf{1}}$ \\
\hline Tebufenozide & 3 & 1 \\
Esfenvalerate & 3 & 1 \\
Trichlorfon & 14 & 2 \\
Triflumuron & 14 & 2 \\
Endosulfan & 14 & 2 \\
Fenpropathrin & 25 & 3 \\
Chlorpirifos & 25 & 3 \\
\hline
\end{tabular}

${ }^{1}$ Toxicity class according to IOBC (Hassan \& Degrande, 1996; Hassan, 1997): class $1=$ little persistent $(<5$ days), class $2=$ slightly persistent $(5-15$ days) and class $3=$ moderately persistent $(16-30$ days).

The insecticides fenpropathrin and chlorpirifos caused less than $30 \%$ of mortality of the larvae only at 25 days after its application, being regarded as moderately persistent (Table 3). That may be explained by the adherence of those chemicals to the cotton leaves, ena- 
bling a longer residual period, causing the larvae to remain for longer exposed to the active ingredient. The persistence of other pyrethroids on Chrysoperla sp. larvae was investigated by Hassan (1992), who found fenpropathrin to be included in class 2 for different predators and parasitoids.

Hassan et al. (1994), found a high mortality of larvae of Chrysoperla sp. under laboratory conditions, when treated with deltamethrin and fenvalerate, which were included in class 3 (moderately persistent). Under field conditions, Hassan et al. (1991) also observed a high mortality of that predator when treated with deltamethrin and fenvalerate, which were found to be in class 3 .

The high toxicity of chlorpirifos was also noticed by Balasubramani \& Swamiappan (1997) in laboratory, who verified a highly deleterious effect on larvae of $C$. carnea when sprayed with that insecticide.

On the basis on that results obtained with fenpropathrin and chlorpirifos, it is recommended that in the case of establishment of a Integrated Pest Management (IPM) for cotton crop by utilizing second-instar larvae of C. externa, the releases of this predator should be done after 25 days from the application of those chemicals.

\section{CONCLUSIONS}

a) The insecticides tebufenozide and esfenvalerate presented a low residual effect for second-instar larvae of Chrysoperla externa, when sprayed on cotton leaves.

b) The insecticides trichlorfon, triflumuron and endosulfan are slightly persistent to the larvae of Chrysoperla externa causing mortality above $30 \%$ up to 14 days after application on cotton leaves.

c) The insecticides fenpropathrin and chlorpirifos are moderately resistant to the larvae of Chrysoperla externa, causing mortality above $30 \%$ up to 25 days after application on cotton leaves.

\section{REFERENCES}

BALASUBRAMANI, V.; SWAMIAPPAN, M. Persistent toxicity of some insecticides to the green lacewing Chrysoperla carnea (Neuroptera: Chrysopidae). Journal of Ecotoxicology and Environmental Monitoring, [S.1.], v. 7, n. 3, p. 197-200, 1997.

CARVALHO, GA..; CARVALHO, C.F.; SOUZA, B.; ULHÔA, J.L.R. Seletividade de inseticidas a $C$ hrysoperla externa (Hagen) (Neuroptera: Chrysopidae). Neotropical Entomology, v. 1, n. 4, p.615621, 2002.
GRAVENA, S.; CUNHA, H. P. Predation of cotton leafworm first instar larvae, Alabama argillacea (Lepidoptera: Noctuidae). Entomophaga, Paris, v. 36, n. 4, p. 481-491, 1991.

GRAVENA, S.; FERNANDES, C. D.; SANTOS, A. C.; PINTO, A. S.; PAIVA, P. S. B. Efeito do buprofezin e abamectin sobre Pentilia egena (Coleoptera: Coccinellidae) e crisopídeos em citros. Anais da Sociedade Entomológica do Brasil, Jaboticabal, v. 21, n. 1, p. 215-222, 1992.

GUEDES, R. N. C.; LIMA, J. O. G. de; ZANUNCIO, J. C. Seletividade dos inseticidas deltametrina, fenvalerato e fenitrotion para Podisus connexivus Bergroth, 1891 (Heteroptera: Pentatomidae). Anais da Sociedade Entomológica do Brasil, Jaboticabal, v. 21, p. 339-346, 1992.

HASSAN, S. A. Guideline for the evaluation of side effects of plant protection product on Trichogramma cacoeciae. In: INTERNATIONAL ORGANIZATION FOR BIOLOGICAL CONTROL OF NOXIOUS ANIMALS AND PLANTS. Working Group "Pesticides and Beneficial Organisms", Montfavet, v. 15, n. 3, p. 1839, 1992.

HASSAN, S. A. Métodos padronizados para testes de seletividade com ênfase em Trichogramma. In: PARRA, J. R. P.; ZUCCHI, R. (Eds.). Trichogramma e o controle biológico aplicado. Piracicaba: FEALQ, 1997. cap. 8 , p. 207-233.

HASSAN, S. A.; DEGRANDE, P. E. Methods to test the side effects of pesticides on Trichogramma. In: PARRA, J. R. P.; ZUCCHI, R. (Eds.). Curso de controle biológico com Trichogramma. Piracicaba: FEALQ, 1996. p. 63-74.

HASSAN, S. A.; ABERT, R.; BIGLER, F. Results of the third joint pesticide testing programme by the IOBC/WPRS working group pesticides and beneficial organisms. Zeitschrift für Angewandte Entomologie, Berlin, v. 103, p. 92-107, 1987.

HASSAN, S. A.; BIGLER, F.; BOGENSCHÜTZ, H.; BOLLER, E.; BRUN, J.; CALIS, J. N. M.; CHIVERTON, P.; CORESMANS-PELSENEER, J.; DUSO, C.; LEWIS, G. B.; MANSOUR, F.; MORETH, L.; OOMEN, P. A.; OVERMEER, W. P.

Ciênc. agrotec., Lavras. V.27, n.4, p.835-839, jul./ago., 2003 
J.; POLGAR, L.; RIECKMANN, W.; SAMSØEPETERSEN, L.; STACBLI, A.; STERK, G.; TAVARES, K.; TUSET, J. J.; VIGGIANI, G. Results of the fifth joint pesticide testing programme carried out by the IOBC/WPRS. Entomophaga, Paris, v. 36, n. 1, p. 55-67, 1991.

HASSAN, S. A.; BIGLER, F.; BOGENSCHÜTZ, H.; BOLLER, E.; BRUN, J.; CALIS, J. N. M.; CORESMANS-PELSENEER, J.; DUSO, C.; GROVE, A.; HEIMBACH, U.; HELYER, N.; HOKKANER, H.; LEWIS, G. B.; MANSOUR, F.; MORETH, L.; POLGAR, L.; SAMS ØE-PETERSEN, L.; SAUPHANOR, B.; STAÜBLI, A.; STERK, G.; VAINIO, A.; VEIRE, M. van de; VIGGIANI, G.; VOGT, H. Results of the sixth joint pesticide testing programme of the IOBC/WPRS. Entomophaga, Paris, v. 39, n. 1, p. 107-119, 1994.

LINGREN, P. D.; RIDGWAY, R. L. Toxicity of five insecticides to several insect predators. Journal of Economic Entomology, College Park, v. 60, n. 6, p. 1639-41, 1967.

TODA, S.; KASHIO, T. Toxic effect of pesticides on the larvae of Chrysoperla carnea. Proceedings of the Association for Plant Protection of Kyushu, [S.1.], v. 43, p. 101-105, 1997.

YU, S. J. Selectivity of insecticides to the spined soldader bug (Heteroptera: Pentatomidae) and its lepidopterus prey. Journal of Economic Entomology, College Park, v. 18, n. 1, p. 119-222, 1988. 